\title{
Parenting Styles and Procrastination Behaviors
}

\author{
Vincent Ming-Wei Woo, Kee Jiar Yeo
}

\begin{abstract}
This study seeks to conduct a systematic review of different perenting styles on procrastination behaviours. Following the PRISMA flow chart, a web-based literature search from 7 electronic databases has been conducted to identify relevant studies published between the year of 2000 to 2018. Based on the inclusion criteria, 11 studies with the sample size ranged between 15 to 685 middle school to undergraduate students were included in this review. It was found that majority of the research focused on the parenting typologies introduced by Baumrind or Maccoby and Martin. While the research on parenting styles mostly evaluated the academically related and general procrastination, limited attention was given to chronic or dysfunctional procrastination. The review found that the negative effects of authoritarian, uninvolved or permissive parenting style towards procrastination behaviour was being described to the greatest extent. In contrast, authoritative parents were inversely related to procrastination.
\end{abstract}

Index Terms: Parenting styles, Parental-child attachment, Procrastination

\section{INTRODUCTION}

Procrastination explains a failure to complete a task within the most appropriate time given.44 People who engaged in procrastination is not solely due to the lack of intentions to work.49 Instead, it is a failure to carry the action to fulfil intention. Such behaviour reflecting a large gap between the intention and action, creating obstacle or anti-intention towards task completion.

Previous literature has examined the internal causes of procrastination such as self-efficacy and emotional intelligence, 15 locus of control and emotional intelligence7, self-esteem5,12,23, and perfectionism21. However, the external causes that explained one's tendency to engage in procrastinating behaviours still remain scarce. One external cause that has been addressed but received limited attention, is the child rearing method used by the parents on their children.

Even though previous researchers have shown that different parenting styles does contribute some degree of impacts to procrastination, $17,30,37$ a review on the past literature is required to provide a catogerisation of how different parenting styles affect procrastination. Therefore, the purpose of this study is to provide a systematic review based on the available literature on different parenting styles towards procrastination behaviours.

Revised Manuscript Received on 14 September, 2019.

Vincent Ming-Wei Woo, Faculty of Accountancy, Finance and Business, Tunku Abdul Rahman University College, 85000, Segamat, Johor. Malaysia. vincentmingweiwoo@gmail.com

Kee Jiar Yeo, Faculty of Education, Universiti Teknologi Malaysia, 81310 UTM Johor Bahru, Johor. Malaysia.

\section{METHODOLOGY}

\section{A. Search Strategy}

We employed the guidelines of preferred reporting items for systematic reviews and meta-analysis (PRISMA) in this study (Refer figure 1). First, we searched through 7 eletronic databases known as Scopus, ScienDirect, Taylor \& Francis Online, Springer Link, SAGE Journals, Web of Science and Google Scholar. A relevant set of keywords or phrases such as 'parenting styles', 'parental control', 'parental autonomy', 'procrastination' was applied to limit the search parameter. As a result, the database search has returned a total of 847 articles. Besides that, a backward-forward search strategy has further identified 4 additional articles. After removing 59 duplicate articles, 788 articles were taken for title and abstract screening.

\section{B. Criteria of Inclusion}

To ensure more refined result, we imposed some criteria of inclusion to all articles during the process of database searching and article screening. The inclusion criteria is being defined as followed:

1. Articles that focused on parenting style and procrastination behaviours;

2. Articles published in English;

3. Articles published between the year of 2000 to 2018;

4. Presented with original data.

5. As a result, a total of 11 articles fulfilled the inclusion criteria and were adopted in this systematic literature review.

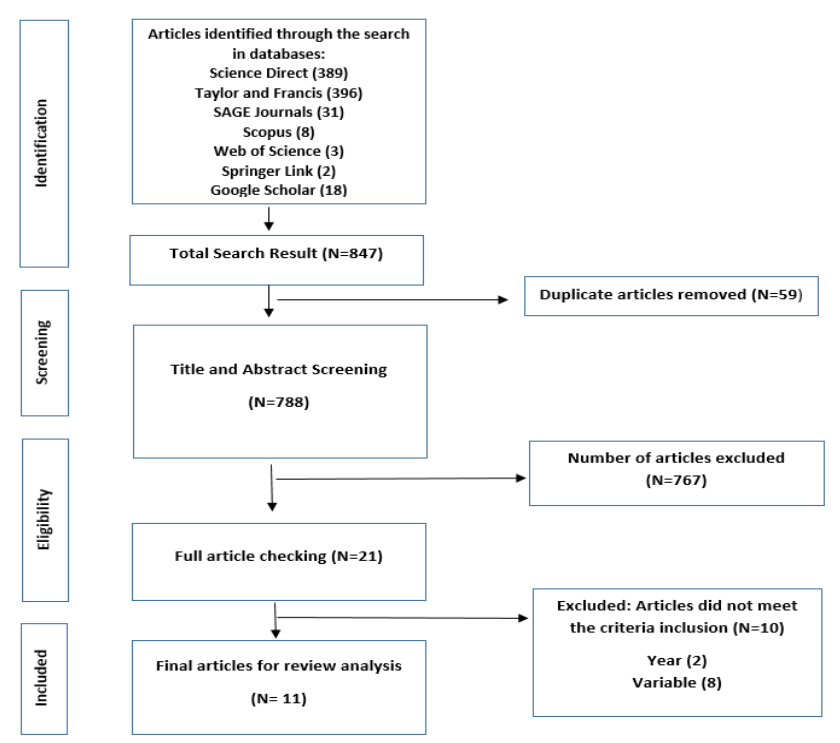

Fig 1: PRISMA Study flow diagram 


\section{RESULTS AND FINDINGS}

\section{A. Summary of Study Characteristics}

Table 1 presented the summary of all articles included in this review. In this context, Iran has recorded the highest number of studies about parenting styles and procrastination (Refer to figure 2). It was found that the issue related to parenting styles and procrastination has received more attention since most studies were published regularly at least once a year since 2014 (Refer to Figure 3).

All studies included in this review used self-reported questionnaire to acquire the information of parenting styles and procrastination behaviours from 15 to 685 middle school and undergraduate students. Parenting styles were defined in different ways across studies, including i) Baumrind's topology of three parenting control models, ii) parental autonomy support and control, iii) parent-child attachment, v) helicopter parenting style, vi) Steinberg's parenting dimensions and vii) Adlerian's parenting concepts (Refer to figure

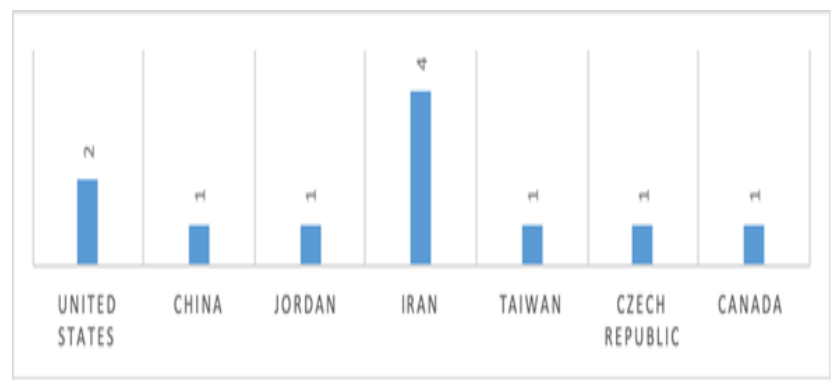

Fig 2: Numbers of publication based on countries

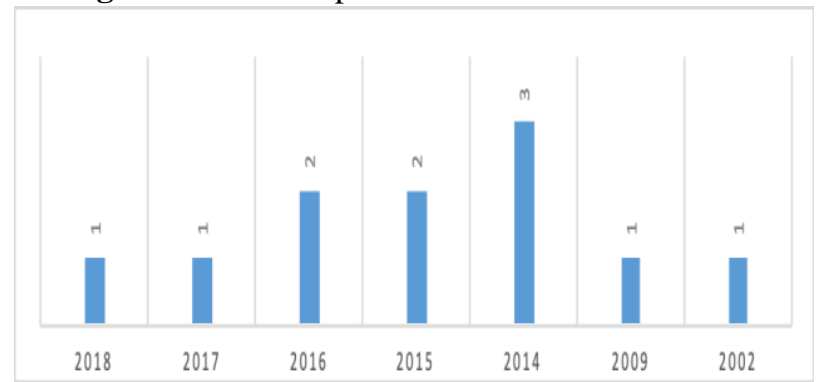

Fig 3: Numbers of publication per year

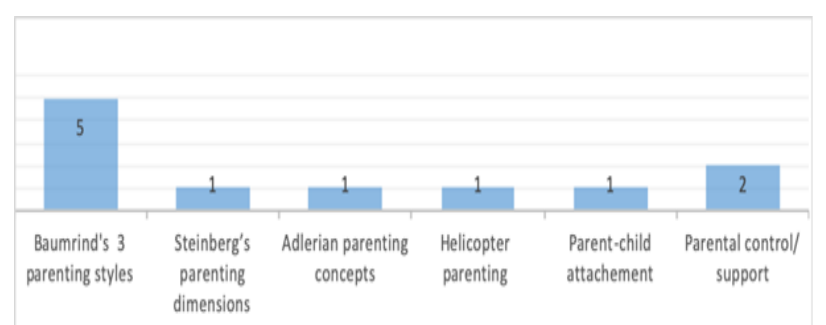

Fig 4: Types of parenting typology adapted across selected studies

Table 1: Study characteristics

\begin{tabular}{|c|c|c|c|}
\hline No & Author & Country & Finding \\
\hline 1 & $\begin{array}{l}\text { Won, S., and } \\
\text { Yu, S.L. }\end{array}$ & $\begin{array}{l}\text { United } \\
\text { States }\end{array}$ & $\begin{array}{l}\text {-Perceived autonomy } \\
\text { support positively predict } \\
\text { time management and } \\
\text { reduce procrastination. } \\
\text {-Parental control does not }\end{array}$ \\
\hline
\end{tabular}

\begin{tabular}{|c|c|c|c|}
\hline & & & $\begin{array}{l}\text { related to time } \\
\text { management. But } \\
\text { positively predicted } \\
\text { procrastination. }\end{array}$ \\
\hline 2 & $\begin{array}{l}\text { Chen and } \\
\text { Chang }^{5}\end{array}$ & China & $\begin{array}{l}\text {-A high quality of parent } \\
\text { adolescent's attachment } \\
\text { has enhanced self-worth } \\
\text { and reduced } \\
\text { procrastination. } \\
\text {-Parental trust and } \\
\text { communication were } \\
\text { positively associated with } \\
\text { self-worth, and indirectly } \\
\text { reduced procrastination. } \\
\text {-Parental alienation was } \\
\text { negatively associated } \\
\text { with self-worth and } \\
\text { indirectly increased } \\
\text { procrastination. }\end{array}$ \\
\hline 3 & $\begin{array}{l}\text { Mahasneh et al. } \\
27\end{array}$ & Jordan & $\begin{array}{l}\text {-Parents who are harsh } \\
\text { and unkind has increased } \\
\text { the academic } \\
\text { procrastination. } \\
\text {-Parents who practiced } \\
\text { acceptance and } \\
\text { involvement with } \\
\text { strictness and supervision } \\
\text { was associated with low } \\
\text { academic } \\
\text { procrastination. }\end{array}$ \\
\hline 4 & $\begin{array}{l}\text { Esmaeili, } \mathrm{N} \text { and } \\
\text { Monadi, } \mathrm{M}^{8}\end{array}$ & Iran & $\begin{array}{l}\text { - Neglectful or easy-going } \\
\text { parents were found with } \\
\text { the highest level of } \\
\text { procrastination. } \\
\text {-Perfectionist parents } \\
\text { make children feel } \\
\text { worthlessness and } \\
\text { procrastinate. }\end{array}$ \\
\hline
\end{tabular}




\begin{tabular}{|c|c|c|c|}
\hline 5 & $\begin{array}{l}\text { Javady, M. J., } \\
\text { and } \\
\text { Mahmoudi,M. }^{19}\end{array}$ & Iran & $\begin{array}{l}\text {-A significantly positive } \\
\text { relation was found } \\
\text { between permissive, } \\
\text { authoritarian parenting } \\
\text { and procrastination. } \\
\text {-No significant relation } \\
\text { was found between } \\
\text { authoritative parenting } \\
\text { and procrastination. } \\
\text {-Only authoritarian } \\
\text { parentings showed a } \\
\text { significant positive } \\
\text { relation with the fear of } \\
\text { success. }\end{array}$ \\
\hline 6 & Hong et al. ${ }^{16}$ & Taiwan & $\begin{array}{l}\text { - Helicopter parenting } \\
\text { style was positively } \\
\text { associated with } \\
\text { procrastination. }\end{array}$ \\
\hline 7 & $\begin{array}{l}\text { Soysa, C.K., } \\
\text { and Weiss, A. }\end{array}$ & $\begin{array}{l}\text { United } \\
\text { States }\end{array}$ & $\begin{array}{l}\text {-Academy } \\
\text { procrastination and } \\
\text { maladaptive } \\
\text { perfectionism } \\
\text { concurrently mediated } \\
\text { the positive relationship } \\
\text { between authoritarian } \\
\text { parents. } \\
\text {-Academic } \\
\text { procrastination and } \\
\text { maladaptive } \\
\text { perfectionism } \\
\text { concurrently mediated } \\
\text { the inverse relationship } \\
\text { between authoritative } \\
\text { parents. }\end{array}$ \\
\hline 8 & $\begin{array}{l}\text { Sedlakova et } \\
\text { al. }^{42}\end{array}$ & $\begin{array}{l}\text { Czech } \\
\text { Republic }\end{array}$ & $\begin{array}{l}\text {-The levels of parental } \\
\text { control were associated } \\
\text { with academic } \\
\text { procrastination. } \\
\text {-High level (Low level) of } \\
\text { parental control were } \\
\text { associated with high } \\
\text { (Low) level of } \\
\text { procrastination. }\end{array}$ \\
\hline 9 & $\begin{array}{l}\text { Zakeri, H., } \\
\text { Esfahani, B. N., } \\
\text { \& Razmjoee, M. } \\
56\end{array}$ & Iran & $\begin{array}{l}\text {-The } \\
\text { 'acceptance-involvement } \\
\text { ' and 'psychological } \\
\text { autonomy-granting' } \\
\text { parenting styles were } \\
\text { significant and negatively } \\
\text { associated with academic } \\
\text { procrastination. }\end{array}$ \\
\hline
\end{tabular}

\begin{tabular}{|c|c|c|c|}
\hline & & & $\begin{array}{l}\text {-The 'behavioural } \\
\text { strictness-supervision' } \\
\text { parenting style had a } \\
\text { significant positive } \\
\text { relationship with } \\
\text { academic } \\
\text { procrastination. }\end{array}$ \\
\hline 10 & $\begin{array}{l}\text { Mortazanajad, } \\
\text { H., Mostafafi, } \\
\text { F., and Vahedi, } \\
\text { S. }{ }^{34}\end{array}$ & Iran & $\begin{array}{l}\text {-Authoritative parenting } \\
\text { was positively associated } \\
\text { with better short-term } \\
\text { self-regulation and } \\
\text { resulted in less } \\
\text { procrastination. } \\
\text {-Unsupportive parenting } \\
\text { was negatively associated } \\
\text { with short term } \\
\text { self-regulation and } \\
\text { resulted in } \\
\text { procrastination. }\end{array}$ \\
\hline 11 & $\begin{array}{l}\text { Pychyl, T.A., } \\
\text { Coplan, R.J. } \\
\text { and Reid, P.A. } \\
39\end{array}$ & Canada & $\begin{array}{l}\text {-A significantly negative } \\
\text { relationship was found } \\
\text { between maternal } \\
\text { authoritative parenting } \\
\text { and procrastination. } \\
\text {-A significantly negative } \\
\text { relationship was found } \\
\text { between paternal } \\
\text { authoritative style with } \\
\text { procrastination. } \\
\text {-A significantly positive } \\
\text { relationship was found } \\
\text { appeared between } \\
\text { paternal authoritarian } \\
\text { parenting and } \\
\text { procrastination. }\end{array}$ \\
\hline
\end{tabular}

\section{TYPES OF PARENTING STYLES}

\section{A. Diana Baumrind's Parenting Styles}

Most included studies have applied parental typology created by Diana Baumrind (5 out of 11). Based on the mechanisms of parental demandingness and responsiveness, three typology of parenting style known as 1) Authoritarian, 2) Authoritative and 3) Permissive have been introduced. Besides, permissive parenting with two distinct categories known as: 1) Permissive indulgent and 2) Permissive uninvolved/neglected were further expanded.28 Each of the parenting style showed different patterns of attitudes towards their children. (Refer to Table 2) 
Table 2: Baumrind's, Maccoby and Martin's four parenting styles

\begin{tabular}{l|l|l}
\hline & High Responsiveness & $\begin{array}{l}\text { Low } \\
\text { Responsiveness }\end{array}$ \\
\hline High & $\begin{array}{l}\text { Authoritative } \\
\text { Supportive rather than } \\
\text { harsh behaviours } \\
\text { Encourage give and } \\
\text { take } \\
\text { Explain reason behind } \\
\text { rules }\end{array}$ & $\begin{array}{l}\text { Authoritarian } \\
\text { Emphasize } \\
\text { obedience } \\
\text { Discourage two } \\
\text { ways } \\
\text { communication } \\
\text { Rigid structure of } \\
\text { controlling }\end{array}$ \\
\hline Low & $\begin{array}{l}\text { Permissive-indulgent } \\
\text { Low enforcement of } \\
\text { rules and authority } \\
\text { Encourage freedom in } \\
\text { making decision } \\
\text { Used extrinsic } \\
\text { rewards to get child to } \\
\text { behave. }\end{array}$ & $\begin{array}{l}\text { Neglected } \\
\text { Disengagement } \\
\text { rom } \\
\text { responsibilities of } \\
\text { children } \\
\text { Lack of closeness } \\
\text { in parent-child } \\
\text { relation } \\
\text { Sense of hostility } \\
\text { towards children. }\end{array}$ \\
\hline
\end{tabular}

The scale developed by Darling and Steinberg in the year of 1993 consisted 3 dimension known as 1) Acceptance-involvement, 2) Psychological autonomy-granting and 3) Behavioural strictness-supervision (Refer to table 3). However, the review found that only 1 study (out of 11) has applied these dimensions.

Table 3: Characteristics of parenting styles 47

\begin{tabular}{|c|c|c|}
\hline $\begin{array}{l}\text { Acceptance-involve } \\
\text { ment }\end{array}$ & $\begin{array}{l}\text { Psychological } \\
\text { autonomy-gran } \\
\text { ting }\end{array}$ & $\begin{array}{l}\text { Behavioural } \\
\text { strictness-supervi } \\
\text { sion }\end{array}$ \\
\hline $\begin{array}{l}\text { Warm and firm } \\
\quad \text { Involved and } \\
\text { sensitive to } \\
\text { children's needs. } \\
\text { Set realistic standard } \\
\text { and clear rules. }\end{array}$ & $\begin{array}{l}\text { Tolerance } \\
\text { against } \\
\text { children's } \\
\text { opinion. } \\
\text { Demonstrate } \\
\text { demographic } \\
\text { discipline in } \\
\text { parent-child } \\
\text { relationship. } \\
\text { Less pressure on } \\
\text { their children to } \\
\text { comply the } \\
\text { rules. }\end{array}$ & $\begin{array}{l}\text { Shape, control the } \\
\text { children with the } \\
\text { absolute } \\
\text { standards. } \\
\text { Does not allow } \\
\text { children to express } \\
\text { own opinion. } \\
\text { Low in } \\
\text { employing } \\
\text { reasoning } \\
\text { guidelines. }\end{array}$ \\
\hline
\end{tabular}

\section{Helicopter Parenting Style}

Another interesting parenting style known as 'Helicopter parent' or 'Cosseting parent', was appeared in the past researches.16 In this context, helicopter parents described the parent who constantly hovering above their children to oversee and close-monitor every aspect of their child's life. In fact, they are over concerned with protecting and helping their children from any potential obstacles.35 Even though

\section{B. Steinberg's Parenting Dimensions}

they used excessive advice and enmeshment, they failed to provide flexibility in adjusting the need for autonomy, decision making for their children.35,41,43

\section{Adlerian's Parenting Concepts}

The parenting concept introduce by Alfred Adler emphasized the effect of pampered and neglectful parenting. Although the children will receive different parental treatment under these two distinct parenting styles, the end result to them will be similar-the feeling of inadequacy. The best approach according to Alder is finding balance point between these two extreme parenting styles. While protecting the children from negative aspects, parents should provide a moderate degree of freedom by allowing their children to explore while still sensing the security of parental influence.

Table 4: Adler's Adlerian parenting

\begin{tabular}{lll}
\hline Pampered & The Balance Point & Neglected \\
\hline $\begin{array}{l}\text { Over-protection and } \\
\text { over-attention. }\end{array}$ & Mutual Respect. & Provides neither \\
Provides extreme & Setting freedom & attention or \\
shelter against & while providing & Strong sense of \\
negatives of life. & limits. & $\begin{array}{l}\text { mistrust of } \\
\text { other. }\end{array}$ \\
\hline
\end{tabular}

\section{E. Parental-child Attachment}

The theory of parental-child attachment emphasized the attachment between parents and children. The secure attachment reflects a sense of warm and trustful that encourage children's adaptive outcome in social, cognitive and behavioural domains4. In contrast, the insecure parent-child attachment such as rejection will result the children to face the difficulty in their social and personal development. The quality of parent-child relationship was measured by the 'Inventory of Parent and Peer Attachment' based on three dimensions. These dimension only applied by 1 study (Out of 11).

Table 5: The Inventory of Parent and Peer Attachment The Inventory of Parent and Peer Attachment

- Parental- child communication

- Parental- child trust

- Parental-child alienation

\section{F. Parental Autonomy Support and Control}

Parental autonomy support and control are being identified as two distinct parenting practices within a person's self-determination theory. Parent who provides autonomy support will encourage children's independent decision making, provide rationale for their decision making and acknowledge the children's feeling.14 In contrast, parent who emphasizes control over their children will tend to create the sense of guilty, threaten and pressure in foresting performance goals. 


\section{G. Procrastination Behaviors}

While categorizing the types of procrastination behaviors from all relevant articles, it was surprised that the majority of the studies ( 8 out of 11) were focused on academically related procrastination. A small number of studies were either looked into the general procrastination ( 2 out of 11 ) or the combination of academic and general procrastination as a single construct ( 1 out of 11). Other types of dysfunctional procrastination such as avoidant and decisional procrastination with the relation of parenting styles, received limited attention.

\section{H. Relationship between Parenting Styles and Procrastination}

The negative effects from the parent who characterized by harsh and unkind, high demand and control but low warmth (authoritarian), low quality of parental-child attachment were being described to the greatest extent. Most studies showed a high level of parental strictness and control will lead to the child's tendency to procrastinate (Table 1).

On the other hand, study that have taken the parents characterized by high demand and high warmth (authoritative), high quality of parental-child attachment, inspiring, acceptance and involvement into account were reported a negative relationship with procrastination. Previous studies also showed that authoritative parents were inversely related to the shaping of needless delay, behavioural avoidance as well as maladaptive perfectionism that constitutes procrastination.39,52

Several past researches have indicated a negative relationship between permissive parenting and procrastination.5,8,27,39,45,55 Besides, diffuse-avoidance was positively correlated with permissive parenting style due to limited consistent rules and guidelines to their children in developing self-control and self-discipline3. As a result, it is more likely for the children to engage in procrastination.

Limited studies were found on overprotective as well as neglected parents towards procrastination. In this context, only 4 out of 11 studies looked into these extreme parenting styles. Parents who are overprotected or over-monitored (helicopter parenting styles) will restrain ideas generation, leading the children becomes very dependent on their parents.16 Besides, children will encounter difficulties in decision making process when received excessively monitored and controlled from their parents.

In contrast, uncontrolled, unsupportive, neglected parents as well as alienation between parental-child relationship were found positively related procrastination.5,8,27,34 For example:

'My father return home late at night and was tired, yet my mother does not address my lesson because he wants to pay attention to my younger brother. When my father addressed my homework, he asked question randomly due to tiredness.'

Student who provided such statement was reported to have a highest level of procrastination due to the dull and apathetic study environment that resulted the loss in motivation. 27

\section{DISCUSSION}

Since children spent most of the time with their parents, parent-child relationship provides an important foundation for children to learn about self-regulate. Some researchers have pointed out that the behaviour of the children is affected by the parent who served as a role model, instructor and reinforcement of certain behaviours. The finding from the study showed that majority of the studies have adapted Baumrind's parenting typologies known as authoritarian, authoritative, permissive parenting styles. Thus, the parenting styles identified by Baumrind and elaborated on by Maccoby and Martin still have a strong empirical basis until today.

Since most of the previous studies were focused on the relation between parenting styles with academically related or general procrastination. More attention is required to focus on other types of dysfunctional procrastination such as decisional and avoidant procrastination. This is because the academically related procrastination is a form of situation-specific task delay. Students may only engage in delaying of academic related task activities but not in other aspects of their life such as looking for a part-time job, attending social events, shopping and etc. Thus, more research to look into the root causes of chronic or dysfunctional procrastination by incorporating the parenting styles, is deemed necessary to enrich the current literature.

While examining the effect of parenting styles and procrastination. Parenting styles characterized high demand with low responsiveness will increase the child's tendency to procrastinate due to the difficulties in developing self-regulated coping skills.46 Besides, frequent interaction with angry, non-responsive, intense and instructive manner were associated with high avoidant behaviour among children19. Therefore, an excessive domination of psychological and behavioural control over from the parents to children will hindrance the development of self-worth and result a high tendency to procrastination.30 While helicopter parents hover and manage their child's life through overly protective and monitor,53 permissive parents provide absolute freedom to their children to do whatever that pleases them. Despite both of these parenting styles started off with good intentions, but continuously hovering and fulfilling demands without condition may create backfire. In this context, permissive indulgent parent who failed to provide proper support to their children will result the difficulty in developing self-regulation skills. On the other hand, excessively monitoring about the children activities make their children become self-handicapping when it comes to task completion and decision-making moment.

Parents who demanding with loves, affectionate, cares and responsive will encourage positive attitudes towards task completion among children. In this context, authoritative parents who encouraged verbal give and take, used reason and shaped to reinforce all important objectives will discuss the reasoning behind discipline. Therefore, their children are intrinsically motivated and able

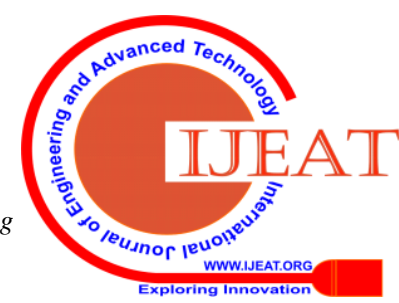


to solve their own problems.1,13,51 Thus, it may lead towards a lower tendency to procrastination.

Even though the research about the impact of uninvolved/neglected parents towards procrastination still remained scarce, parents who failed to nurture will cause their children involve in more externalizing behaviours. In some extreme cases, uninvolved and neglectful parents will choose to reject their children. They only provided some basic needs such as clothes, foods and shelter but not involved in their lives4. If the parents fail to fulfil the basic nurturing requirement, their children will have higher tendency to become a poor self-regulated learner and lack of self-confidence.

\section{CONCLUSION}

This paper seeks to provide a systematic literature review based on previous studies to analyse the relationship between two variables, known as parenting styles and procrastination behaviours among adolescents. Through the review, we can conclude that different parenting styles adopted by parents will develop different level of self-regulatory skills to their children. In the context, even though both authoritarian and authoritative parenting styles will exercise more psychological control and demand from their children, but the magnitude of responsiveness is totally different. In contrast, permissive and uninvolved parenting are either providing excessive freedom to or no psychological control over their children.

In terms of procrastination, different level of parenting styles will bring different implication to such maladaptive and negative behaviour that undermines learning or self-regulating. However, there is much need to look into the effect of parenting styles so that the issue of procrastination among adolescents can be understood. This review will help to provide a better understanding especially to the parents to adopt and develop a healthy relationship with their children in reducing the tendency to procrastinate.

\section{REFERENCES}

[1] Alegre, A. Parenting styles and children's emotional intelligence: what do we know? The Family Journal: Counselling and Therapy for Couples and Families,2011, 19 (1), pp 56-62.

[2] Baumrind, D. Parenting styles and adolescent development. In J. Brooks-Gunn, R. Lerner, \& A. C. Petersen (Eds.), The encyclopedia of adolescence, 1991, pp 746- 758.

[3] Berzonsky, M. D. Identity style, parental authority and identity commitment. Journal of Youth and Adolescence. 2004, 33(3), pp 213-220.

[4] Bowlby, J. Attachment and loss (Vol 1): Basic Books. 1969.

[5] Chen,B.-B., Chang,L. Procrastination as a fast life history strategy. Evol.Psychol. 2016,14, pp 1-5.

[6] Darling, N. Parenting style and its correlates. Clearing House on Elementary and Early Childhood Education.1999.

[7] Deniz, M., Tras, Z., \& Aydogan, D. An investigation of academic procrastination, locus of control, and emotional intelligence. Educational Sciences: Theory and Practice,2009, 9(2), pp 623-632.

[8] Esmaeili, N. \& Monadi, M. Identifying the causes of academic procrastination from the perspectives of male middle school students. International Journal of Humanities and Cultural Studies, 2016.

[9] Ferrari, J.R., \& Olivette, M. J. Parental authority and the development of female dysfunctional procrastination. Journal of Research in Personality, 1994,28, pp 87-100.
[10] Ferrari, J.R., Johnson, J.L. and McCown, W. Procrastination and Task Avoidance: heory, research and treatment. New York: Plenum Press. 1995.

[11] Ferrari, J. R., O’Callaghan, J., \& Newbegin, I.Prevalence of procrastination in the United States, United Kingdom, and Australia: Arousal and avoidance delays among adults. North American Journal of Psychology, 2005,7(1) pp, 2-6.

[12] Flett, G.L., Blankstein, K.R., and Martin,T.R."Procrastination, negative self-evaluation and stress in depression and anxiety," Procrastination and Task Avoidance: Theory ,Research, and Treatment,1995,pp 137-167.

[13] Furnham, A., \& Cheng, H. Perceived parental behavior, self-esteem and happiness. Social Psychiatry Epidemiol, 2000,35, pp 463-470.

[14] Grolnick, W. S., \& Ryan, R.M. Parent styles associated with children's self-regulation and competence in school. Journal of Education Psychology, 1989, 81(2), pp143-154.

[15] Hen, M., \& Goroshit, M. Academic procrastination, emotional intelligence, academic self-efficacy, and GPA. A comparison between students with and without learning disabilities. Journal of Learning Disabilities, 2014, 47(2), pp 116-124.

[16] Hong, J.C., Hwang, M.Y. Kuo, Y.C. \& Hsu W.Y., Parental monitoring and helicopter parenting relevant to vocational student's procrastination and self-regulated learning. Learning and Individual Differences, 2015, 42, pp 139-146.

[17] Huang, J. and Prochner, L. 'Chinese parenting styles and children's self-regulated learning'. Journal of Research in Childhood Education,2004, 18, pp 227-238.

[18] Janis, I.L., \& Mann, L. Decision-making: a psychological analysis of conflict, choice and commitment. New York: Free Press.1977.

[19] Javady, M.J., Mahmoudi, M. The relationship between perceived parenting styles and academic procrastination and fear of success. International Academic Journal of Humanities, 2015. 2(10). pp31-49.

[20] Karavasilis, L., Doyle, B. A., \& Markiewicz, D. Associations between parenting style and attachment to mother in middle childhood and adolescence. International Journal of Behavioral Development,2003, 27 (2), pp 153-164.

[21] Kaur, H. and Kaur, J. 'Perfectionism and procrastination: cross cultural perspective', FWU Journal of Social Sciences, 2011,5(1), pp 34-50.

[22] Knaus, W.J. Procrastination, blame, and change, Journal of Social Behavior and Personality,2000, 15(5), pp 153-166.

[23] Klassen, R.M., Krawchuk, L.L., and Rajani,S. Academic procrastination of undergraduates: low self-efficacy to self-regulate predicts higher levels of procrastination. Contemp. Educ.Psychol. 2008,33, pp 915-931.

[24] Kochanska G, Aksan N, Prisco TR, Adams EE. Mother-child and father-child mutually responsive orientation in the first two years and children's outcomes at preschool age: Mechanisms of influence. Child Development. 2008,79(1), pp 30-44.

[25] Lamb, ME., Lewis, C., The development and significance of father-child relationships in two parent families. In: Lamb, ME., editor. The role of the father in child development. Fifth. Hoboken, NJ: Wiley; 2010. Pp 94-153.

[26] Lay, C. H. At last,my research on procrastination. Journal of Research in Personality, 1986, 20(4), pp 474-495.

[27] Mahanesh, A. M., Bataineh, O.T., Al-Zoubi, Z. A. The relationship between academic procrastination and parenting styles among jordian undergraduate university students. The Open Psychology Journal. 2016.pp 25-34.

[28] Maccoby, E. E., \& Martin, J. A. Socialization in the context of the family: Parent-child interaction. P. H. Mussen (Ed.) \& E. M. Hetherington (Vol. Ed.), Handbook of Child Psychology: Socialization, Personality, and Social Development. 1983,4, pp. 1-101.

[29] Martin A, Ryan RM, Brooks-Gunn J. When fathers' supportiveness matters most: maternal and paternal parenting and children's school readiness. Journal of Family Psychology. 2010,24(2), pp 145-155.

[30] Mih, V. Role of parental support for learning autonomous/control motivation, and forms of self-regulation on academic attainment in high school students: A path analysis. Cognition, Brain, Behavior. An Interdisciplinary Journal,2013, 17, pp 35-59.

[31] Michael D. B. Identity style, parental authority, and identity commitment. Journal of Youth and Adolescence. 2004, 33(3),pp 213-220.

[32] Mohammad, E.M., Liaghat, R. \& Madah, L, Study of the effect of parenting styles and self-regulation on academic achievement. International Research Journal of Applied and Basic Sciences. 2013,4,pp 19-24.

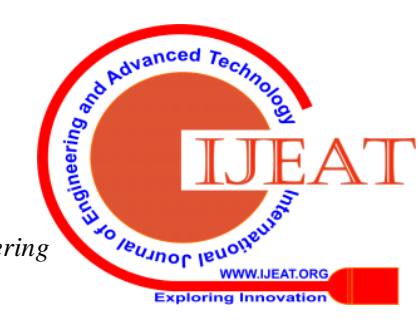


[33] Mohammad, E.M.,Liaghat, R. \& Madah, L. Academic anxiety, academic procrastination, and parental involvement in students and their parents. British Journal of Education Psychology. 2013, 69,pp 345-361.

[34] Mortazanajad, H., Mostafafi, F., \& Vahedi, S. Self-regulation and dimensions of parenting styles predit psychological procrastination of undergraduate students. Iranian Journal of Psychiatry. 2009, 4(4), pp 147-154.

[35] Odenweller, K. G., Booth-Butterfield, M., \& Weber, K. Investigating helicopter parenting, family environments, and relational outcomes for millennials. Communication Studies, 2014, 65, pp 407-425.

[36] Owen DR, Rupprecht R, Nutt DJ. Stratified medicine in psychiatry: a worrying example or new opportunity in the treatment of anxiety? Journal of Psychopharmacology.2013, 27(2),pp 119-122.

[37] Piotrowski, J. T., Lapierre, M. A. and Linebarger, D. L. 'Investigating Correlates of Self-regulation in Early Childhood with a Representative Sample of English-speaking American Families', Journal of Child and Family Studies, 2012, 22, ( 3),pp 423-436.

[38] Peterson, JB.; Flanders, JL. Play and the regulation of aggression. New York: Guilford Press. 2005,pp 133-157.

[39] Pychyl, T. A., Coplan, R. J., \& Reid, P. A.M. Parenting and procrastination: Gender differences in the relations between procrastination, parenting style, and self-worth in early adolescence. Personality and Individual Differences. 2002,33, pp 271-285.

[40] Sarkadi, A., Kristiansson, R., Oberklaid, F., \& Bremberg, S. Fathers' involvement and children's developmental outcomes: A systematic review of longitudinal studies. Acta Paediatrica.2007, 97,pp 153-158.

[41] Schiffrin, H. H., Liss, M., Miles-McLean, H., Geary, K. A., Erchull, M. J., \& Tashner, T. Helping or hovering? The effects of helicopter parenting on college students' well-being. Journal of Child and Family Studies. 2014,23,pp 548-557.

[42] Sedlakova, J., Mylek, V., Caplova, K., Prochazka, J., Vaculik, M., \& Jezek, S. Parental control of child as a predictor of academic procrastination. Prague, Proceedings of the 11th International Conference on Efficiency and Responsibility in Education. 2014, 9, pp 694-702.

[43] Segrin, C., Givertz, M., Swaitkowski, P., \& Montgomery, N. Overparenting is associated with child problems and a critical family environment. Journal of Child and Family Studies.2015, 24,pp 470-479.

[44] Silver, M. and Sabini, J. Procrastination, Journal for the Theory of Social Behaviour, 1981, 11, pp 207-221.

[45] Soysa, C. K., \& Weiss, A. Mediating perceived parenting styles-test anxiety relationships: Academic procrastination and maladaptive perfectionism. Learning and Individual Differences, 2014, 32,pp 77-85.

[46] Stansbury, K., \& Zimmerman, K. L, Relations among child language skills, maternal socialization of emotion regulation, and child behavior problems. Child Psychiatry and Human Development. 1999,30 (2),pp 121-143.

[47] Steinberg, L., Lamborn, S., Dornbusch, S., Darling, N. Impact of parenting practices on adolescent achievement: authoritative Parenting, school involvement, and encouragement to succeed. Child Development. 1992,63,pp 1266-1281.

[48] Steinberg, L. We know some things: Adolescent-parent relationships in retrospect and prospect. Journal of Research on Adolescence.2001, 11,pp 1-19.

[49] Steel, P, The nature of procrastination: A meta-analytic and theoretical review of quintessential self-regulatory failure. Psychological Bulletin, 2007,133,pp 65-94.

[50] Tamis-LeMonda C, Shannon J, Cabrera N, Lamb M. Fathers' and mothers' play with their 2- and 3- year-olds: Contributions to language and cognitive development. Child Development. 2004,75(6)pp, 1806-1820.

[51] Tafarodi, W. R., Wild, N., \& Ho, C. Parental authority, nurturance, and two-dimensional self-esteem. Scandinavian Journal of Psychology.2010, 51,pp 294-303.

[52] Turner, L. A., \& Turner, P. E,The relation of behavioral inhibition and perceived parenting to maladaptive perfectionism in college students. Personality and Individual Differences.2011, 50,pp 840-844.

[53] Van Eck Peluchette, J., Kovanic, N., \& Partridge, D. Helicopter parents hovering in the workplace: what should HR managers do? Business Horizons. 2013,56, pp 601-609.

[54] Vogel CA, Bradley RH, Raikes HH, Boliler K, Shears JK. Relation between father connectedness and child outcomes. Parenting, Science and Practice. 2006,6(2-3), pp189-209.

[55] Won, S., \& Yu, S. L. Relations of perceived parental autonomy support and control with adolescents' academic time management and procrastination. Learning and Individual Differences, 2018, 61, pp 205-215.
[56] Zakeri, H., Esfahani, B. N., \& Razmjoee, M. Parenting Styles and Academic Procrastination. Procedia - Social and Behavioral Sciences, 2013, 84, pp 57-60.

\section{Authors Profile}

Vincent Ming-Wei Woo, Faculty of Accountancy, Finance and Business, Tunku Abdul Rahman University College, 85000, Segamat, Johor. Malaysia. vincentmingweiwoo@gmail.com

Kee Jiar Yeo, Faculty of Education, Universiti Teknologi Malaysia, 81310 UTM Johor Bahru, Johor. Malaysia. 